\title{
MASS INCARCERATION: WHO PAYS THE PRICE FOR CRIMINAL OFFENDING?
}

\author{
TRACEY L. MEARES \\ University of Chicago
}

Has the massive increase in the number of Americans imprisoned over the last two decades been helpful or harmful to the communities that all would agree are those most in need of deliverance from crime and the negative effects that accompany it? That is the question that Lynch and Sabol attempt to answer here.

When the engineers of policies devoted to making prison sentences both harsher and more prevalent developed their ideas, they would likely be surprised that such a question could be asked. These boosters claimed that their law-and-order program clearly benefited minority inner-city residents by addressing and reducing the high levels of crime residents regularly experience. 1 A statement made by former Attorney General William Barr concerning heavy penalties for certain drug offenders is representative: "The benefits of increased incarceration would be enjoyed disproportionately by Black Americans" (Tonry, 1995, quoting Barr) And, we might add, in the neighborhoods in which they live. Lynch and Sabol tell us, however, that to the extent that there has been a benefit in the form of crime reduction from mass incarceration, it does not appear to have devolved to the community or even neighborhood level. This is true despite the fact that much evidence clearly demonstrates that removal of offenders is not distributed equally across geographic space. ${ }^{2}$

Responding to this reality, scholars have articulated theories describing how mass incarceration concentrated at the community or neighborhood level could hamper institutions of informal social control (Nagin, 1998; Rose and Clear, 1998). ${ }^{3}$ Drawing on Shaw and McKay's foundational work, these scholars have focused on various social processes, including (1) the prevalence, strength, and interdependence of social networks; (2)

1. See Dilulio (1996) (pointing to numerous black community leaders and others speaking about the problem of black-on-black crime and the importance of law enforcement addressing this issue). For an argument reflecting the sentiments of the boosters, see Kennedy (1994:1273). "Blacks subject to a relatively heavy punishment for crack possession are burdened by it, [but] their law-abiding neighbors are helped by it insofar as the statute deters and punishes drug trafficking in their midst."

2. Lynch and Sabol discuss evidence of potential crime rate drops and national and state levels, but not community levels.

3. Lynch and Sabol highlight two.

$\begin{array}{llll}\text { VOLUME } 3 & \text { NUMBER } 2 & 2004 & \text { PP 295-302 }\end{array}$ 
the extent of collective supervision by neighborhood residents and the level of personal responsibility they assume for addressing neighborhood problems; and (3) the rate of resident participation in voluntary and formal organizations (Rose and Clear, 1998; Sampson and Wilson, 1995; Wilson, 1996). The hypothesis is straightforward: When the processes of community social organization are prevalent and strong, crime and delinquency should be less prevalent, and vice versa. Note, however, that these community social organization processes do not have to be activated in favor of norms that support law-abiding behavior; they are simply a form of infrastructure. For this reason, I have used the metaphor "norm highways" to describe these processes in other work (Meares, 1998, 2000). The metaphor helps to clarify the fact that the social infrastructure of a community by itself can either inhibit or support crime. Whether infrastructure supports a community's efforts to resist crime will depend on the kinds of norms that are transmitted among individuals who live in a neighborhood. Like autos on an actual highway, norms can travel in any direction on "roads" of neighborhood social infrastructure. Thus, the "norm highways" of neighborhoods may facilitate crime as well as prevent it. 4

Lynch and Sabol collect and present data relevant to these ideas. They conclude that although there is some data relevant to the negative impact of mass incarceration on former inmates' connections to the labor market, on the so-called marriage market, and on community solidarity and voluntary participation at the community level, much of the evidence is weak or spotty. What should we make of this? In this short reaction essay, I would like to do two things. First, I would like to extend Lynch and Sabol's literature review by adding a summary of research from a new qualitative study of 50 families in Washington, D.C. This new study, soon to be published by the University of Michigan Press, fills in the some of the gaps left by the large empirical studies that Lynch and Sabol canvass. Second, I would like to offer some observations about what "state of research" articles in the vein of Lynch and Sabol's suggest about what policy makers should be doing —or perhaps more particularly, what policyminded scholars ought to be promoting.

\section{DOING TIME ON THE OUTSIDE}

Anthropologist (and soon-to-be lawyer) Donald Braman conducted more than 200 interviews over a three-year period with 50 families living in the Washington, D.C. area. Each of these families was located in a poor,

4. See Patillo-McCoy (1999) (finding that dense social ties "positively affect[ed] informal and formal supervision of youth. . . But. . . Groveland's dense networks similarly allow for organized criminal enterprises" (p.70)). 
mostly minority neighborhood where the male incarceration rate exceeded $2 \%$ (Braman, 2002). These interviews contain valuable insights concerning the effects of incarceration on family life. At the same time, Braman's detailed accounts lead to the inexorable conclusion that the massive increase in the number of American prison inmates has led to a scenario in which inmates are being held less rather than more accountable for criminal offending.

\section{STRAINS ON THE FAMILY}

Although Braman connects mass incarceration to father absence in the District of Columbia (in an analysis of 576 block groups, he shows that the male incarceration rate has a statistically significant and independent contribution on father absence from a family, holding constant male unemployment, median income, educational achievement, gender, and race) (Braman, 2004a), perhaps even more compelling and relevant to the theories outlined above are the detailed stories Braman presents of the economic difficulties imposed on the families of the incarcerated. Lynch and Sabol recognize that families may well miss the income that incarcerated individuals can provide the family. Missing in their account, however, are the additional financial costs to families of imprisonment. When a family member is imprisoned, the family remaining behind continues contact with him or her (usually him). Through a recounting of the experiences of several families, Braman explains that the most costly expense that families of the incarcerated must regularly bear is collect calls from the inmate. It turns out that correctional facilities contract out for phone services, and facilities select carriers based on which carrier will provide the facility with the highest fee, not which company will provide cheapest service for the inmate. According to the families Braman (2004a:4) interviewed, $\$ 10$ fees for 10-minute conversations were not uncommon. In addition to phone calls, families bear the expenses of visits, which can include car rental or some other form of transportation, hotels, childcare, and of course, food (Braman, 2004a:151; Le Blanc, 2003). 5 If costs associated with maintaining legal battles on appeal and with stress-related medical expenses that some left-behind family members experience when a loved one is incarcerated are added to the list, it is easy to see how these direct costs of incarceration add up quickly - especially when such expenses must be borne by families in the worst position to deal with them. 6

5. LeBlanc (2003) describes in addition to the costs just mentioned, the expenses one young mother incurred for the purchase of new clothes for her children so the father would see them "dressed-stylishly."

6. The direct annual expenses one family incurred resulting from a family member's incarceration come to $\$ 12,680$ (See Braman, 2004a: 151, Table 2). This amount is borne by a handful of people, none of whom earned more than $\$ 20,000$ per year. 
These financial hits are not easily accounted for by the large-scale empirical investigations that Lynch and Sabol describe in their piece. They are most easily exposed by the kind of careful in-depth and long-term interviewing that Braman and Fishman, whose work Lynch and Sabol do describe, have done. This qualitative scholarship adds substantial credence to the claims of scholars who posit that mass incarceration negatively impacts families in disadvantaged neighborhoods rather than helps them.

Braman's work also supports Lynch and Sabol's warning that a focus on marriage to the exclusion of other kind of family arrangements may well understate the participation of inmates in families and thus the negative impacts of removal of a male offender from his neighborhood and family context. For example, Braman tells Davida's poignant story. Davida saw her father arrested by police after he returned to the family from prison. After the arrest, he was sent back to prison. While her father was incarcerated the second time, Davida was sexually assaulted by her stepfather, held in a juvenile facility, and involved in prostitution to help support herself and her grandmother. Here are 16-year-old Davida's own words (Braman and Wood, 2004):

My father is very important to me and grandmother, because by me not being old enough to get a regular job that maintain a stable place for us to stay, and my grandmother's retired, she only gets one check a month, we don't have much money to do this, or, you know, food or whatever. . . I'm bending over backwards trying to keep everything intact while he's not here, and by me being my age, it's hard, you know? I'm going through a hell of a time while he's not home.

If one way that mass incarceration negatively impacts the ability of families and communities to exert social control is that social networks may be weakened or even torn asunder when a family member is removed from the neighborhood, household, or immediate family context, then we want to be able to measure that breach in some way. Counting the number of divorces or relative increases in single-parent headship of families, even at the neighborhood level, cannot begin to capture the nuanced processes that qualitative studies can reveal. For example, in addition to highlighting the negative impacts on children from the removal of their fathers as a regular presence in their lives, Braman also shows how family members left behind also withdraw from their own families. Increased economic costs sometimes force female partners of the incarcerated (or their mothers or sisters) to turn to extended family for financial assistance, childcare, and other resources. But the assistance extended family members can offer is limited by their own constrained finances. Eventually, extended family members begin to resent the burden of caring for family 
members whose partners are incarcerated. One woman Braman interviewed shares, "My mother can't even hear me talk about him. She'll be like, 'What? Are you crazy?'" (Braman, 2004b). This woman stopped talking to her own extended family about her husband and ended up turning only to his sisters for help. This kind of isolation from family networks is clearly inconsistent with promotion of social norms in favor of positive neighborhood outcomes.

\section{SOCIAL ISOLATION AND TRANSMISSION OF NORMS}

The church is a key institution in the lives of many African-Americans, whether rural or urban (Lincoln and Mamiya, 1990). African-Americans are in many ways the most religious people in America. 7 The church, moreover, is a key site for the transmission of norms associated with social control and law-abidingness (Meares, 2002; Patillo-McCoy, 1999). Yet, Braman (2004a:235) shows that kin of the incarcerated can become more estranged from church-based networks, as opposed to becoming further ensconced within them:

Most family members do not need to be humiliated in church [by disclosing that a family member is imprisoned] to understand that faith and public censure are not mutually exclusive - indeed the social organization of church life often defines the relationship of one to the other. For this reason, church is a setting in which many families in the District are made keenly aware of the tension between collective celebration of faith and the possibility of moral censure. As one woman responded when asked if she could turn to church members for support, "Church? I wouldn't dare tell anyone at church."

This ambivalence is borne of the sometimes conflicting roles of the church both to support its members in need, while providing a role model of self-sufficiency and personal responsibility. Church leaders and members are role models who are always at risk of having their image tarnished by those who "fall from grace."

From an informal social control perspective, withdrawal of family members of those imprisoned from active church life has predictable negative consequences. Participation in formal organizations is a community structural factor that theoretically should reinforce the crime-reduction benefits

7. According to recent Gallup polling, some $82 \%$ of blacks (versus $67 \%$ of whites) are church members; $82 \%$ of blacks (versus $55 \%$ of whites) say that religion is "very important in their life"; and $86 \%$ of blacks (versus $60 \%$ of whites) believe that religion "can answer all or most of today's problems" (John Dilulio, Jr., 2002) 
of both teenage supervision and friendship networks. Local formal organizations provide community residents with important opportunities to create overlapping relationships. Overlapping relationships subject the residents of a community to expectations and obligations in multiple contexts, and these obligations and expectations often are transferable across different contexts. The existence of multiple, overlapping relationships among a community's residents has important implications for crime prevention (Krohn, 1986). ${ }^{8}$ Friendships among neighbors that are reinforced through individual participation in church groups are very likely to increase supervision of teenage peer groups in a community and increase information transmission. Withdrawal from these groups should have the opposite consequences. Indeed, Braman notes that in addition to withdrawing from church life, family members of those who are incarcerated retreat from work relationships and other friendships. Although, they are not locked up, these families are stigmatized by incarceration. They experience a profound "social silence" (Braman, 2004a:237-238).

\section{POLICY CHOICES}

Is there enough evidence to suggest that the families of those who are incarcerated (and likely whole communities) bear substantial costs that are not overcome by any crime-reduction benefit? How sure do we need to be to come to that conclusion? Statistical significance is a standard that is a good one for discovering scientific truth, but it may well be too cautious to guide practical action. "Political significance" may often be good enough (Meares and Kahan, 1998). The tentative results that Lynch and Sabol collect, along with detailed work such as Braman's, are, perhaps, enough for policy-minded researchers to advocate for different solutions to address criminal offenders.

It is true that there are data indicating some crime-reduction benefits from current imprisonment policy. The question is whether those benefits are worth the costs. The United States spends over $\$ 40$ billion annually on imprisonment (Marciniak, 2002). Not $\$ 1$ of this amount is devoted to the families described in this essay. These are costs that are currently unaccounted for by promoters of the current approach.

Today much greater attention is being paid to prisoner reentry. This reality is practically unavoidable in large urban areas. The City of Chicago, headed by a mayor well known for his devotion to neighborhoods, has even created a cabinet-level position devoted to the issue. Addressing

8. Krohn (1986) calls this process "multiplexity" and explains it this way: "If a person interacts with the same people in differing social contexts it is likely that his behavior in one context will be affected by his behavior in another" (p. 583). 
reentry and the problems for returning prisoners, their families, and neighborhoods is an acute issue. It is good that resources are being devoted to it. However, more attention must be paid to the imprisonment policy that generates these issues. If massive imprisonment is not generating the kind of reductions in crime that the costs of the program would imply, then questions of accountability come to mind. The foundational premise of incarceration today is that offenders are sent to prison to deter them from offending again, keep them from harming others (at least those outside prison walls), and to "pay" the price for breaking the law. Lynch and Sabol argue that we should question whether the first two goals are being met. Donald Braman asserts that nonoffending family members are the ones who are "paying," in a sense, for crime. This state of affairs seems at best misaligned and at worst nonsensical. Policy-minded researchers in this area can make a contribution. The research agenda that Lynch and Sabol outline is a start.

\section{REFERENCES}

Braman, Donald

2002 Families and incarceration. In Marc Mauer and Meda Chesney-Lind (eds.), Invisible Punishment: The Collateral Consequences of Mass Imprisonment. New York, NY: New Press.

2004a Doing Time on the Outside. Ann Arbor, Mich.: University of Michigan Press. In press.

2004b Families and the moral economy of incarceration. Unpublished Manuscript (under review).

Braman, Donald and Jennifer Wood

2004 From one generation to the next: How criminal sanctions are reshaping family life in urban America. In Jeremy Travis and Michelle Waul (eds.), Prisoners Once Removed: The Impact of Incarceration and Reentry on Children, Families and Communities. Washington, D.C.: Urban Institute Press.

DiIulio, Jr., John J.

1996 My Black Crime Problem, and Ours. City Journal 6:14-28.

2002 Saving souls-and cities. In Abigail Thernstrom and Stephan Thernstrom (eds.), Beyond the Color Line: New Perspectives on Race in America. Stanford, Calif.: Hoover Institution Press.

Kennedy, Randall

1994 The state, criminal law, and racial discrimination: A comment. Harvard Law Review 17:1255 and 1273.

Le Blanc, Adrian Nicole

2003 Random Family: Love, Drugs, Trouble, and Coming of Age in the Bronx. New York: Scribner.

Lincoln, C. Eric and Lawrence H. Mamiya

1990 The Black Church in the African-American Experience. Durham, NC: Duke University Press. 
Ed Marciniak

2002 Standing room only. Commonwealth 2:129.

Meares, Tracey L.

1998 Place and crime. Chicago-Kent Law Review, 73:669, 676.

$2000 \quad$ Norms, legitimacy and law enforcement. Oregon Law Review 79:391, 395.

2002 Praying for community policing. California Law Review 90:1593, 1615-1619.

Meares, Tracey L. and Dan M. Kahan

1998 Law and (norms of) order in the inner city. Law \& Society Review 32:805, 806-808.

Nagin, Daniel

1998 Criminal deterrence research at the outset of the twenty-first century. In: Michael Tonry (ed.), Crime and Justice: A Review of Research. Chicago, Ill.: University of Chicago Press.

Patillo-McCoy, Mary

1999 Black Picket Fences: Privilege and Peril Among the Black Middle Class. Chicago, Ill.: University of Chicago Press.

Rose, Dina and Todd Clear

1998 Incarceration, social capital and crime: Implications for social disorganization theory. Criminology 36:441.

Sampson, Robert J. and William Julius Wilson

1995 Toward a theory of race, crime and urban inequality. In John Hagan and Ruth Peterson (eds.), Crime and Inequality. Stanford, Calif.: Stanford University Press.

Tonry, Michael

1995 Malign Neglect: Race, Crime, and Punishment in America. New York: Oxford University Press.

Wilson, William Julius

1996 When Work Disappears: The World of the New Urban Poor. New York: Knopf.

Tracey Meares received her B.S. in General Engineering from the University of Illinois, and her J.D. from The Law School. She joined the University of Chicago faculty in 1994 after serving as an Honors Program Trial Attorney in the Antitrust Division of the United States Department of Justice. Prior to serving as a Department of Justice prosecutor Ms. Meares clerked for Judge Harlington Wood, Jr. of the U.S. Court of Appeals for the Seventh Circuit. Ms Meares's teaching and research interests center on criminal procedure and criminal law policy, with a particular emphasis on empirical investigation of these subjects. In addition to teaching at The Law School, Ms Meares has an appointment as a Research Fellow at the American Bar Foundation. She is also a faculty member of the University of Chicago Center for the Study of Race, Politics and Culture. 


\title{
THE CHALLENGE OF MASS INCARCERATION
}

\author{
ANNE MORRISON PIEHL \\ Harvard University
}

The tremendously high incarceration rates in the United States provide thorny challenges for students of crime and criminal justice policy. The current rate of incarceration in jails or prisons is around 1 per 140 U.S. residents (Harrison and Beck, 2003) As is well known, this rate increased dramatically over the past 30 years, and it is perhaps leveling off or at least slowing in its rate of increase. Despite this long history of rising rates of incarceration, scholars and policy makers are really just beginning to come to terms with what these facts mean for society and for policy.

Calculations documenting how highly concentrated incarceration is by geography and demography reveal that the impression given even by these high aggregate rates of incarceration is insufficient to capture the reality relevant to some populations. Although it is not surprising that the incidence is concentrated, its extent is staggering: For black males in central cities and urban areas, the level of incarceration approaches $10 \%$ on a given day. Results from various papers by Lynch and Sabol, Rose and Clear (1998), and many others (see citations in Lynch and Sabol, this volume) document the concentration of incarcerated or newly released offenders in particular neighborhoods within disadvantaged communities. These findings have been replicated in a number of communities using various types of data (administrative, survey, and ethnographic).

Now that we have good information on the basic facts, Lynch and Sabol's "Assessing the Effects of Mass Incarceration on Informal Social Control in Communities" challenges us to contemplate the implications of the extremely high rates of incarceration in particular communities. There are a couple of types of challenges implicit and explicit in their contribution-challenges for research on the topic and perhaps more fundamentally challenges to the framework for thinking about incarceration policy.

\section{COMMUNITIES, CRIME, AND INCARCERATION}

Community life is enhanced by the absence of crime. Violence, the fear of violence, and disorder impede prosocial activities like work and socializing in the neighborhood. At the same time, incarceration can have negative effects on a community due to the disruption of social and economic

$\begin{array}{llll}\text { VOLUME } 3 & \text { NUMBER } 2 & 2004 & \text { PP 303-308 }\end{array}$ 